\title{
Memory Mechanisms in Tan's The Joy Luck Club and Darraj's The Inheritance of Exile
}

\author{
Sara Fadla \\ University of Badji Mokhtar-Annaba (UBMA), Algeria \\ Yousef Awad (Corresponding Author) \\ The University of Jordan, Jordan \\ Email: y.awad@ju.edu.jo
}

Received: $23 / 11 / 2020$

Accepted: 16/01/2021

Published: 01/03/2021

Volume: 2 Issue: 2

How to cite this paper: Fadla, S. \& Awad, Y. (2021). Memory Mechanisms in Tan's The Joy Luck Club and Darraj's The Inheritance of Exile. Journal of Critical Studies in Language and Literature, 2(2), 11-21

DOI: https://doi.org/10.46809/jcsll.v2i2.54

Copyright (C) 2020 by author(s) and Global Talent Academy Ltd. This work is licensed under the Creative Commons Attribution International License (CC BY 4.0).

http://creativecommons.org/licenses/by/4.0/

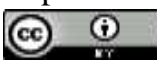

\begin{abstract}
This article discusses the mechanisms of memory and the schemes of transcending past recollections in Chinese American novelist Amy Tan's The Joy Luck Club (1989) and Arab American novelist Susan Darraj's Inheritance of Exile (2007). Both texts highlight the dialectical representations of remembrance in diasporic narratives. Consequently, the article underscores the intersectionality of memory, healing, and ethnic identity in both novels. Tan's and Darraj's novels foreground memory narratives in which self-recovery and wholeness of identity are closely examined. The paper is a comparative study that examines the dialectics and divergent forces of memory representations in Tan's and Darraj's novels through scrutinizing the power of remembering in strengthening and/or justifying the characters' enchantment of the present or their glorifying of the past.
\end{abstract}

Keywords: Amy Tan, Susan Darraj, Ethnic Women, Remembrance, Healing, Identity

\section{Introduction}

This paper examines how female protagonists in Chinese American novelist Amy Tan's The Joy Luck Club (1989) and in Arab American novelist Susan Darraj's The Inheritance of Exile (2007) negotiate and resist exile through memory. The significance of this study lies in showing how through postmemory strategy, memory becomes a constructing force that empowers the daughters of immigrant women as remembrance becomes a necessity for the daughters' psychological recovery. In addition, the study examines how Tan's and Darraj's novels are both stories of geographical displacement and immigration and how both texts represent the workings of memory in notable ways. Both texts also narrate a mother-daughter relationship and the impact of this troubled relationship on the forcing of Chinese / Arab cultural identities. Presenting the cultural heritage, mothers try to keep hold of their American-born daughters and inject their own cultural traditions and heritage into their souls. Torn between a mother who wants to teach a natal culture and a self that refuses that culture, the daughters eventually experience an identity crisis. Paradoxically, it is through the voice of their mothers that they come finally to terms with their true selves. 
Thus, the power of the mother in these texts lies in empowering a hybrid self in their daughters. They teach them how to take "American circumstances" and keep the ethnic part of themselves to stand out and embrace the "art of invisible strength" (Tan, 95). Moreover, both texts share the same fragmented structure. They are both divided into four chapters narrating the stories and memories of four mothers and their daughters. As such, this paper argues that the characters in Tan's and Darraj's texts return to their memory repertoires in search of reconciliation with their past lives and, thus, reconstructing their present ethnic identities. In other words, memory and remembrance define the characters' positionalities in a geographically and culturally different nation. In The Joy Luck Club and The Inheritance of Exile, remembrance becomes a healing instrument through which the characters succeed in re-constructing or reconciling with an ethnic identity.

The Joy Luck Club and The Inheritance of Exile form a tapestry of immigrant stories and memories. Both narrate the stories of four Chinese and Arab mothers and their American-born daughters living in America. They are also divided into four chapters. In Tan's novel, each chapter consists of four sections. The first chapter and last one are stories told by the mothers except for the recently dead Suyuan Woo. Her story is narrated by her daughter Jing-mei Woo. The two inside chapters are divided into four stories narrated by the four daughters. The novel respectively showcases the different struggles that the Chinese-American face in America. The mothers' past recollections serve as an empowering vehicle in the text. Their narratives come to inject a missed part of their daughters' identities; that is, the ethnic Chinese part. Through these recollections, the American-born daughters are introduced to a Chinese culture they have never experienced. Similarly, The Inheritance of Exile is about four young women and their mothers who live in South Philadelphia. It tells the stories of four young Arab immigrants in the United States: Nadia, Aliyah, Hanan, and Reema. The novel explores the daughters' negotiations between an American self and an Arab identity. The Inheritance of Exile is divided into four chapters, each narrating the story of one of the daughters. Yet, the stories of the mothers are sandwiched between their daughters' narratives. Unlike the daughters whose narratives are set in the present and account for their daily experiences in America, the mothers' narratives that are respectively squeezed between their daughters' accounts are mostly stories of their past lives and experiences in Palestine.

As can be noticed from the above outline, memory in these texts is the thread that weaves together the stories of these women. In other words, both novels are memory narratives that function as a binding force between mother and daughter. In fact, they can be seen as a reservoir of memories. Thereof, in the selected fiction, memory works as a healing force that helps the characters instigate action and readjust their positionalities within the borders of America. In addition, through transmission of memories between a mother and her daughter, a feminist solidarity is then possible. Accordingly, the drafting of a short historical background of Chinese and Arab immigration and settlement in the United States seems to be vital for properly analyzing both novels.

\section{Chinese American and Arab American Immigration and Settlement History}

The Chinese American immigration happened through two phases. Early Chinese immigrants arrived to the United States in the mid-1800s, while the last came from the late 1970s till now (Jie Zong \& Jeanne Batalova). These phases were demarked by the passage of constitutional acts (The Chinese Exclusion Act 1882, the Magnuson Act 1943, and the HartCeller Act 1965). The first Chinese immigrants worked as cheap labors. They came for mining gold. They are "best known for their contribution to the construction of the Transcontinental Railroad, the completion of which united the country economically and culturally" (William Wei, para 2). Indeed, their role in the country's economic growth is undeniable. Yet, they were also subject to extreme racism which led to the passage of the Chinese Exclusion Act. The latter banned the Chinese from entering the United States for around ten years. Its passage "was a watershed event in American History" (Para 5). It has been until 1943 that the Chinese immigrants were allowed again to country due to the Magnuson Act. The latter has not only allowed Chinese immigration but granted citizenship to those immigrants already living in the States. This act was passed after China's declaration of alliance with the United States during World War II.

Studying the lives of Chinese American women and community, Huping Ling (1998) affirms that the early Chinese immigrants "were pushed by such forces in China as political persecution and the lack of economic opportunity" (17). The passage of the 1965 Immigration Act opened the door for more immigration movements to the United States. By then, Chinese women immigrants flooded into the country. This "bachelor society," as Min Zhou (2009) describes it, "has experienced unprecedented demographic and social transformation into a family community" (46). Huping Ling argues that "early Chinese immigrant women were 'pushed' by forces in China and 'pulled' by attractions in the United States" (20). Indeed, one of the reasons that pushed Chinese women immigrants is their urge desire to family re-union. Most of them are the wives and daughters of Chinese men living in the United States. Additionally, like their male counterparts, some of them are students or professionals who escaped the feudal China to better their lives abroad.

Similarly, Arab American community has been marked by three waves of immigration. According to Randa A. Kayyali (2006), the first wave has arrived between 1880s and 1920s, while the second has stretched between 1925 and 1965 . The last and most contemporary wave of Arab immigrants landed ashore since the 1960s. The early Arab immigrants were poor people who found America as their "entrepreneurial Eden" (Naff, 2). According to Alixa Naff (1985), these immigrants took peddling as their fundamental economic activity as a way of gaining money rapidly. She points out that this activity allowed the process of assimilation of these immigrants in the way it obliged them to learn English and the American way of life. Yet, like the other ethnic communities, the Arab American immigration has been demarked by different US immigration laws. As 
pointed out earlier when discussing Chinese immigration to the United States, the passage of acts like Immigration Act (1917), The Quota Act (1921) and the Johnson-Reed Quota Act (1924) curtailed the number of immigrants and banned migration from outside Northern and Western European countries. Consequently, the Arab immigration rate has fallen down dramatically due to these new legislations.

In the post WWII era, the number of Arab immigrants increased again because of the change in the American immigration policy. More importantly, in the 1960s, the United States has passed more immigration reforms calling for family re-union and the admittance of skilled labor. The Immigration and Nationality Act of 1965 allowed more Immigrants and Arabs to enter the States. This increase has been also marked by the economic hardships and the political unrest in most Arab countries. Arab immigrants were either fleeing wars, poverties, or looking for better chances. For example, the 1948 Arab-Israeli war, the Nakba, and the Six-Days War (1967) caused Palestinians' massive immigration first to other Arab countries and then to the United States. In addition, the contemporary immigrants are noticed to be largely students and professionals who are better-educated in comparison with the previous immigrants' generations. They entered the States as an effect of their "lure of economic opportunity" and the looking for a prosperous future (Kayyali, 23).

Like Chinese Immigrants, in the first wave, Arab men immigrants outnumbered women immigrants. In the years between 1899 and 1910, women immigrants from Arab countries formed around 30 percent of Arab migrants whereas between 1919 and 1930, Arab women immigrants' rate boomed to reach 47 percent (Barkan, 195). The early women immigrants were housewives who moved to the United States to join their husbands. The later women immigrants have been known to be more independent and intellectual. This generation "had careers with, and independently of, their husbands" (Barkan, 718). They have become more successful women within the borders of America as they are well aware of their rights. Agreeably, this "success of incoming female migrants post 1965 can be attributed," in Eliott Robert Barkan's (2013) view, "to the burgeoning activity of women in the Arab world" (ibid). In other words, Arab women immigrants who entered the country in post 1960s are known to be successful women educators, politicians, authors, and activists. Among these successful women, there are Arab-American women who formed a literary tradition of their own. Their literature comes as the "voice of an [immigrant] woman to speak the truth without the filter of translation, without the influence of others sliding in to corrupt her story" (Darraj, 2).

\section{Transcending the Dialectical Borders of Memory}

Theoretically speaking, this study is grounded in works on memory, psychology, philosophy, and diaspora. Paul Connerton (1989) states that "our experience of the present very largely depends upon our knowledge of the past" (2). In other words, our present is nothing but a continuum of the past. In a similar vein, Ben Xu argues that "memory is [. . .] an experiential relationship between past and present, projecting a future as well" (265). The present and the future are realistically constructed through past experiences. Moreover, the present self is soundly constructed when reconciliation with the past self is achieved. In this context, Jan Assman and Marianne Hirsch have introduced a theory of generational memory transmission. Assman puts forward her concept of "communicative memory" which is socially and culturally mediated. Similarly, Hirsch theorizes her "postmemory" where memories are transmitted from one generation to another. Additionally, Sigmund Freud engages in theorizing memory in reference to the repressed experiences and healing mechanism. Together with Joseph Breuer, Freud argues that hysterical behavior stems from the pressure of the unremembered memories. Breuer and Freud suggest that "in the remembering of the experience, whether real or imagined, is the healing" (White, 44).

Arguably, since both texts are written by women about women stories, it is pivotal to address feminist theories of memory. Gender and ethnicity complexities entwine with the study of memory in feminist analytical and critical reviews of cultural issues. Terry DeHay (1994) observes how memory is as important to women as the exposure of gender injustices in women's writings. A woman "needs to have clear vision to her past, in order to re-vision the present" (31). Accordingly, in feminist thought, the act of remembering is a tool of liberation. It is "the main liberatory factor for those in doubly marginal situations" (Janine Rider, 86). Sometimes, it even becomes the exit door from one's reality. More explicitly, Kate Chedgzoy notes that "feminist scholarship is itself a work of memory that has retrieved many women from oblivion as historical actors and recorders" (as qtd in Reading, 196). Therefore, feminism offers a new approach to memory studies in which an understanding of the voice of minority is respectively underlined.

Accordingly, feminist memory studies address questions of gender, subalternity, and ethnicity in past narratives. It "revises, reorders, refigures, resignifies" past stories (Greene, 294). Additionally, Anna Reading, a leading figure in gender and memory studies, laments how women's contribution to the field of memory has been overlooked. This is not just because women are described as unable to record a historical memory, but also due to the unimportance of the tropes of gender in memory studies. Yet, Reading opines that feminist memory studies "has challenged mainstream Memory Studies through a growing emphasis beyond national boundaries and on intersectionalities of gender and other aspects of identity" (210). Feminist work on memory mobilized the study of memory beyond the borders of nationalism. It dovetails gender and subaltern issues within the fabric of memory narrative. In this light, Tan's and Darraj's texts can be viewed as "feminist revision[s], seeking to inscribe another (woman's) story within the storehouse" of ethnic American fiction (Plate, 31).

Tan's and Darraj's texts, as memory narratives, unearth stories of Chinese and Arab Americans and present psychological therapeutic modes through storytelling. Naeimeh Tabatabaei Lotfi (2014) suggests that "there must be a 'will' behind sharing memories;" it is the will to be heard and freed from the weights of the past (143). To meet such ends, healing is only possible 
through means of communication. Unsurprisingly, psychology promotes for the motto "Narrate yourself" (Straub, 219). In immigrant literature memory is communicated within the family borders. Assman (2008) introduces the concept of "communicative memory." This memory stands for the past events that are transmitted or revealed through means of communication. "Communicative memory;" Assman further declares, "lives in everyday interaction and communication" (111).

Jügen Straub (2008) believes that a "particularly important modus of this communication is storytelling" (222). The latter helps healing since it serves as the "bridge across the black hole of trauma" (Bloom, 16). Indeed, storytelling becomes a curative act which guarantees mental and psychological health. Freud and Beuer (2000) argue that "a person's memory of humiliation is corrected by his putting the facts right, by considering his own worth, etc" (9). A traumatic memory becomes a vehicle for empowerment through its storytelling association and transmission of endurance and strength. Accordingly, storytelling mends past wounds, unravels stories of oppression and subjugation, and nurses the present self. In Tan's and Darraj's novels, memory is a narrative of survival and a psychological exit for the traumatized immigrants who feel cultural alienation. Moreover, the process of recalling and narrating traumatic pasts is a curative and a self-empowering strategy.

In fact, the analysis of both novels delineates the mothers' different memory narratives as a vehicle of empowerment and the power of memory transmission in the daughters' narratives. The mothers' recollections instigate endurance, survival, and triumph. The therapeutic nature of memory in the narrative is manifested through the technique of storytelling. The study also draws on the concept of "counter-memory." The latter is a concept introduced by George Lipsitz (2001). He suggests that this memory is "a way of remembering and forgetting that starts with the local, the immediate, and the personal. . . . Counter-memory looks to the past for the hidden histories excluded from the dominant narratives" (213). Such memory includes the subaltern narratives of the past. It respectively "attack[s] the androcentric model" by contesting androcentric narratives and unraveling the past misdeeds of patriarchy inflicted on women (Melman, 12). Thereof, counter-memory narratives un-silence women voices and unearth their repressed stories. In this respect, Tan seems to adopt this countermemory strategy to uncover the past stories of the Chinese mothers in her text. Lindo Jong's story stands as the best example of this kind of memory narrative where the androcentric biased codes of marriage are exposed, and therefore, it will be examined thoroughly in the coming pages.

\section{Critical Review of The Joy Luck Club and The Inheritance of Exile}

The Joy Luck Club has been a fertile ground that received a good number of reviews and analyses. Walter Shear (1993) investigates the generational and cultural differences in Tan's novel. He believes that Tan's novel along with Maxine Hong Kingston's is empowered by the current feminist ideas in the examinations of the Chinese-American generational dilemma. Shear further explains that both texts focus on the mother-daughter relationship and the impact of diaspora in engendering rupture in the Chinese family. This relationship that is shaped by conflict serves as an allegory to the conflict between the old world and the new one, between the past and the present. Similarly, Michelle M. Wood (2012) analyzes the importance of the mother-daughter relationship for the Chinese Americans and highlights the role of geography in shaping such relation. The novel, according to Wood, demonstrates that the tension in mother-daughter relationships is due to the inability of the mothers and their daughters to share "cultural myths of strength and identity because they do not share the geographical landscape" (83). Yet, by arguing that cultivating strong individual identities allow women "glimmers of understanding" about themselves and their relationships to a larger social context, Wood unconsciously overlooks the importance of memory in the negotiation and renegotiation of ethnicity. Both Shear and Wood focus on the significance of the geography and the positionality in Tan's novel. This study valorizes the power of remembrance in the making of immigrant women personalities and in guaranteeing the continuity of ethnic cultures. Tan powerfully spots the Chinese American attempts to "fashion a voice for themselves in a culture where women are conditioned to be silent" (Foster, 2009, 18).

Unlike Tan's text, there is scant critical literature on Susan Darraj's novel. Yousef Awad's "Displacement, Belonging and Identity in Susan Muaddi Darraj's The Inheritance of Exile" is one of few pieces that critically evaluate the novel. In this essay, Awad (2015) asks a pivotal question: "Where is home?" Having asked that, the essay tries to explore the complexity of defining what home is. Accordingly, he asserts that the novel depicts the concept of home as a "site of contesting and conflicting ideas as issues of race, ethnicity, gender, class and generational differences [. . .] intersect" (1). Awad focuses on the workings of home in respect to Arab American immigrants (1). In contrast, this study's focus is on the mechanisms of memory in the making of an ethnic self. In other words, while Awad's article investigates how Darraj's novel defines "home", this paper highlights the importance of memory in constructing a whole and undivided identity.

In a comparative study, Marta Bosch-Vilarrubias (2016) analyses Susan Darraj's novel in relation to Leila Halaby's West of the Jordan. Both novels are combined together in the study as they describe the relationship of four young American daughters with their fathers. Vilarrubias opines that both texts "ponder Arab American fatherhoods . . [and] offer a variety of enactments of rujula (Arab masculinity) that counter homogenous views of Arab manhood" (138). Her study highlights how Darraj's novel presents a portrayal of non-negative masculinities that serve as a "de-stereotyping of Arab men in the United States" (149). The novel presents a demise of Arab neopatriarchy. Yet, different from Vilarrubias study, the present study falls under the prism of feminist and memory studies. It respectively highlights the mechanisms of Arab women immigrants' empowerment through the re-enactment of memory. 


\section{The "art of invisible strength": Representation of Memory in Tan's The Joy Luck Club}

Tan's novel presents four different traumatic stories. These are stories of the horrors of war, loss, and gender injustices. The first section "Feathers from a Thousand Li Away" narrates mothers' past lives in China. Each of the mothers has "unspeakable tragedies they had left behind in China and hopes they couldn't begin to express in their fragile English" (8). Suyuan Woo's story is a story of war horrors and loss. Recently declared as dead, she tells her story through the voice of her daughter, Jing-mei Woo. The latter believes that Joy Luck is her "mother's Kweilin story" (9). Jing-mei thinks that her mother's Kweilin story is nothing but a "Chinese fairytale" as it keeps being changed every time it is narrated (15). Kweilin is the place where Suyuan lived after her marriage with her two baby daughters. But due to the Japanese threatening advance, Kweilin people were forcibly demobilized. This story "grew darker, casting long shadows into her life, and eventually into [her daughter's]" (9). The effects of the story are remarkable on the mother's psyche and on her daughter's, too. It is the story of her loss of her daughters. In the text, there exist three versions of the story: the first version and the second are narrated by the mother while the last version is narrated by her husband. While the first version ends on a happy note, the second ends with the unspeakable trauma of loss. The third version is told by Jing-mei's father in an attempt to narrate a closure of the story.

Suyuan narrates the first version of the Kweilin story. She remembers how she "sat in the dark corners of [her] house with a baby under each arm, waiting with nervous feet [. . .] But you can't stay in the dark for so long" (11). Suyuan narrates the horrors that the Japanese attack during World War II sculptured in their consciousness. This version ends on a happy note, narrating the idea of a gathering to play a mahjong game and "bragging about her skill at the game" (15). The second version, which is narrated by the mother, ends with a traumatic loss. This memory is triggered by Jing-mei's annoying nagging on a transistor radio. Seeing her daughter's insistence, Suyuan remembers her lost daughters. Because of the Japanese attack on Kweilin, Suyuan leaves to Chungking. She ends the story by saying that "[b]y the time [she] arrived in Chungking [she] had lost everything except for three fancy silk dresses" (16-17). The closure of the story is only known by the end of the novel where Jing-mei and her father travel back to China to meet the lost daughters. He discloses that she "knew she would die of her sickness, or perhaps from thirst, from starvation, or from the Japanese" (344). Unable to see her babies die, she wraps some jewelry, money, and photographs with the babies' names and the address of the family and stuffed them under their clothes. Walking for so long, she fainted and was found and saved by an American missionary lady. By then, she could not go back to save her daughters.

Consequently, this changeability of the Kweilin story confirms that there is no fine absolute version of the past. Past stories are constantly changed and modified. As such, every "form of memory - the individual memory of personal experiences, cultural memory or transgenerational 'postmemory' (Hirsch) - depends on re-articulations and re-enactments. Its contents are necessarily modified and invented as they are remembered" (Baronian et al, 12). Such narratives are vivid, plural, and re-generating each time they are recalled. In the case of Suyuan, her memory of child loss is continuously regenerated as the mother is unable to re-live the trauma. She tries to repress it and modify the ending each time she narrates it.

Like Suyuan's traumatic narrative, An-mei's storytelling is characterized by pain and loss. Her story is entitled "scar," where both her physical and psychological scars are unraveled in the narrative. An-mei goes back to the time of her childhood where she lived an unhappy life and witnessed her mother's suicide. She narrates the story of her harsh and unlucky infancy with her grandmother. Both her brother and herself were forbidden to talk about their mother who was prohibited from the house. It is until later in the novel that it is revealed that An-mei's mother was chased out due to her falling for an old rich man and becoming his fourth concubine. An-mei's memory narrative is vivid and most alive. In this context, Freud and Beuer argue that traumatic memories as such "persist for a long time with astonishing freshness and with the whole of the affective colouring" (9). This is true not only for An-mei but even for the other mothers. The mothers' stories of the past are attempts to resist being relegated to oblivion. An-mei genuinely "can see what happened more than sixty years ago" (258). Going back to the time of her mother's banishment, she remembers the general mood, the discussion, the exact odors' of the food and other details.

An-mei's memory of her mother is divided into two parts: the first is narrated at the beginning, and is then continued in the last section. Though divided, the story is not fragmented. This continuity is echoed in the mother/daughter relationship. In "Queen Mother of the Western Skies," An-mei carries forward the story of her mother and their round up. She ruefully reminiscences that at that first meeting, her "mother was a stranger to [her] . . . But I knew she was my mother, because I could feel her pain" (258). To An-mei, this bond is reconstructed through transmitting and sharing painful life stories. Their bond is only strengthened when seeing her mother's receiving the pain of losing her own mother, Popo. Subsequently, Anmei's mother unhesitatingly sacrifices herself for her daughter. When dying, she whispers to her daughter that she would accept the pain of "kill[ing] her own weak spirit so she could give [her] daughter a stronger one" (289).

Before her suicide, the misery of An-mei's mother is disclosed earlier to her daughter through Yan Chang who becomes a storyteller, as well. An-mei's mother was hoodwinked by Wu Tsing and his Second Wife in an attempt to stop the former from spending his money in teahouses and fulfill his desire for a son. Subsequently, like Suyuan's story, this narrative of loss becomes a narrative of empowerment. An-mei's mother empowers her daughter with strength and endurance which An-mei, in return, tries to instill in her daughter, Rose. Thus, one may convincingly argue that in Tan's novel, memory does not only reinforce mother-daughter relations since the former communicates her past experiences to the latter, but it is also a modus vivendi that involves survival strategies, empowerment and perseverance. An-mei's physical scar becomes associated with 
the psychological one. When her mother's "long smooth fingers rubbing and searching under [her] skin, finding the spot that was my smooth-neck scar . . . It was as though she were rubbing the memory back into [her] skin" (42). The memory floods back once her mother rubs the scar. An-mei immediately remembers the incident of her mother's banishment. Cast out, Anmei's mother tried to reach for her daughter, but the boiling soup pot spilled over An-mei's neck. Her physical scar becomes the trigger for her psychological wound.

Similar to Suyuan's and An-mei's, Lindo's storytelling is a counter-memory narrative. Her marriage is ordered by the village matchmaker when she was only two years old (Tan, 48). Indeed, the traditional Chinese marriage "was strictly regulated by a ritual system. [. . . ] it was arranged by the parent's order and on a matchmaker's word" (Ge Feng and Zhengming Du, 50). Lindo describes how marriage works in these days. Marriage was a promise from one family to the other. Lindo contests that "even if [she] had known [she] was getting such a bad husband, [she] had no choice, now or later." (49) Lindo's village is ruled by patriarchal codes. Daughters are deprived their right to choose a husband. Mothers-in-law look for girls who will look after the household, old people, and their husbands properly. Lindo remembers how she was betrothed to the Huangs family. Her marriage was held when she was sixteen. Lindo happily accounts for the failure of this marriage, declaring that a "lot of bad luck fell on [their] wedding day" and very few people came as it rained (57). She recalls how she has been fooled into a life of obedience and servitude (55). Living in such a community, Lindo learns the art of being obedient. In fact, the Huangs succeed in injecting "their thinking into [her] skin" (56). This memory relates to her endurance and survival mechanism where her silence prepares her for rebellion.

Lindo narrates her story of survival as she succeeds in escaping the life of domesticity that the Huangs impose on her. Looking into the mirror, she was surprised seeing that she "was strong. [She] was pure. [She] had genuine thoughts inside that no one could see, that no one could ever take away from [her]. [She] was like the wind" (58). Knowing herself-worth, she decides to undo this marriage without breaking the promise of her parents. She reminisces how she, in return, fools the Huangs into freeing her from "the comforts of [such] marriage" (66). This was at the time when Huang Tatai started to expect a grandson. Playing on their belief in superstitions, Lindo plots a strategy to escape the marriage. She pretends to have a vision of the ancestors who came to see the appropriateness of the marriage. Her dream story was so solid that her motherin-law believed it all. Lindo reported the ancestors' anger and their threats of revenge as the marriage was not approved. Being frightened of the ancestors' threats, the Hunags set Lindo free and gave her enough money to travel to America. Consequently, this memory re-enforces Lindo's self-worth and re-instills her agency.

Finally, Ying-Ying St. Clair's story is a narrative of identity loss despite the fact that she lived a comfortable childhood compared to the other mothers. She feels herself lost and wishes to be found. The first memory goes back to the year of 1918 where the Moon Lady Festival took place. Accidently, Ying-Ying fell into the waters of the lake and has been fished out by another boat. Returning her to her family boat, it was a dream-like. Finding herself unmissing, she "felt [she] was lost forever" (85). In fact, early that night, the wish she wanted the Moon Lady to grant her is to be found. Accordingly, in the last section, she narrates her second memory from her life in China. Ying-Ying was around seventeen when she was married to a bad man. Like Lindo, this marriage leaves a scar in her mind. It is a horrible experience that she cannot even dare speaking her first husband's name. After their marriage, she unexpectedly falls in love with this husband. Yet, he abandons her to live with an opera singer instead when she was pregnant with his son. She avenges herself by aborting this child.

Ying-Ying believes in the power of storytelling. She realizes that the only remedy for finding her selfhood and reconnecting with her daughter is storytelling. She regrets all the years she kept her memories hidden from her daughter. She confirms that it is because she "remained quiet for so long now [her] daughter does not hear [her]" (69). Ying-Ying regrets how she used to watch her daughter "as though from another shore" (293). Yet, seeing the troubled life she is living, YingYing decides to empower the Chinese self of her daughter by passing on her story. She believes that storytelling "is the only way to penetrate her [daughter's] skin and pull her to where she can be saved" (ibid).

Narrating different women's stories, Tan's novel represents the binding force of memory through manifesting the therapeutic and empowering effects it has on both first and second-generation immigrants. Memory becomes the process in which a mother's and a daughter's voice engage in a continuous dialogue of past and present stories. In this context, Hirsch (1989) writes that the "story of female development [ . . ] needs to be written in the voice of mothers as well as in that of daughters . . . Only in combing both voices, in finding a double voice that would yield a multiple female consciousness, can we begin to envision ways to live life afresh" (161). Through these past narratives, the daughters succeed in meeting with their respective ethnic selves. As an attempt to guarantee a generational continuity, the mothers transmit their experiences through story-telling. It proves the healing power of memory on a woman's consciousness. It re-enforces feminist solidarity and ethnic positionality as ways of empowerment.

\section{The Inheritance of Exile: Memory as a Ground for Empowerment}

Like Tan's mothers, the mothers in Darraj's text are allowed to access agency and empowerment through past recollections. Suzanne Guerlac contends that "[m]emory images [. . . ] serve a useful function in relation to action. Indeed, there would be no voluntary action without them" (128). Siham, Lamis, Layla and Huda, who immigrated to America in the sixties, draw on their memories of home to cope with overwhelming socioeconomic and cultural issues they encounter in their new country. More clearly, memory helps Siham re-adjust in the foreign land and get a successful business. Lamis's reminiscences help her overcome her social class complex. Layla is moved by her own past reflections and is put into action 
by writing a letter addressing her daughter's indifference. Lastly, Huda represents the essence of the mothers' narratives: it is a "postmemory" narrative in which she transmits her life stories to her daughter. Just as in Tan's novel, narratives in Darraj's novel highlight the role of memory in empowering these American-born daughters.

In The Inheritance of Exile, the mothers believe in their cultural rootedness in Palestine, and hence, they feel lost, displaced and uncomfortable in the United States. Consequently, this sense of loss and foreignness is only mended through snatches of memory. Thereof, in the mothers' narratives, memory becomes a strategy of familiarization and re-adjustment. In other words, it is the reconstructing force that helps the older generation to adapt and undo their marginalization by transforming the new environment into a familiar space. This practice of transformation is a "practice of habitation," which Bill Ashcroft (2001) describes as "more than the occupying of a location, it is itself a way of being within which, and through which, place comes to be" (159, emphasis in original). In other words, the mothers inhabit a space that is reconstructed and transformed in ways that disregard geographical boundaries. Thereof, their memory has "the power to create a universal space" (129). Indeed, it "turns location, any location, into home, into owned place" (159). This transformative strategy through past recollections blurs temporal and spatial borders.

During the process of their homebuilding, the mothers try to become familiar with the new space by engaging in a memory recollection in relation to the present situations. Sara Ahmed (2003) describes this process of homemaking as "creating both pasts and futures through inhabiting the grounds of the present" (9). The present is created through the past and the remembrance of the past is shaped by the present moment. Accordingly, the mothers infuse the past with the present to emphasize a continuity of self and a sense of home, belonging and rootedness. Indeed, in the words of Hirsch and Smith (2002), identity "becomes a story that stretches from the past to the present and the future" (8). Consequently, these mothers attempt to create a new homely space in the new neighborhood in South Philadelphia.

To start with, Siham's narrative is about her early stages of settlement and the difficulty of assimilation in America. Siham, Nadia's mother, feels her new neighborhood as "an island, lonely, despite the flow of people" (18). Such feelings invite memories of home in Siham's mind in an attempt to re-color and domesticate the present image. The Italian Market serves as the trigger for memories of home or what Pierre Nora (1996) calls "Lieux de mémoire" (xvii). The market reminds Siham of the "Old City quarter of Jerusalem" (18). She remembers how in Jerusalem she "could bargain with the peddlers [and how] they were insulted if you did not engage them in some level of negotiations" (19). In remembering the Old City market, she brings the vividness and colorfulness of it into the Italian Market to ease her feelings of unfamiliarity, estrangement and displacement. In "blend[ing] the two cities together," Siham succeeds in overcoming her present feelings of frustrations and her feelings of loss (Awad, 4). This memory of the market also makes her go back to the memory of her marriage where Nader, her husband, was amazed by "her ability to bring prices down" (Darraj, 19). What is important also in that narrative is the positive nature of memory. This is seen in Siham's memory of the weather in Jerusalem. This memory is motivated by Siham's wonderings when a blond woman who turns out to be Nader's first wife visits them. After this memory, she finds a way to help her husband to pay the bills. She decides to embroider sofa pillow cases and "put [them] for sale in [Mrs. Donato's] shop" (23). Consequently, Siham's memories, literally and metaphorically, enrich her present.

Lamis's story, in contrast, is about her social class complex and how memory helps her exorcise this evil attitude and outlook. Upon seeing Siham's new dishwasher, Lamis begrudges Siham's acquisition of this new appliance since it aggravates Lamis's feelings of inferiority. She is jealous of Siham who is ladylike and "the closest thing to the bourgeoisie [. . .] in [their] South Philadelphia neighborhood" (57). In America, Lamis feels amused at the sense of equality that the country offers. When Siham buys the dishwasher, Lamis's perception of a classless society is gravely disrupted. Fuming and disgruntled, Lamis's memory of her Lebanese friend, Samira, is summoned. She and Samira attended Temple University. Samira has a "dorm room and freedom that [Lamis] envied" (61). Her feelings of inferiority are further unraveled as she confesses her admiration of Samira's Lebanese accent which is "so airy and crisp and glittering with French words, unlike [her] guttural village dialect" (61). Agitated by this memory, Lamis decides to remind Siham of where they all came from. In Siham's house, Lamis curses the new dishwasher as a way to purge her anger and distress. Doing so, she feels "satiated, [and] strangely triumphant" (65). Yet, she eventually realizes that her "class conscience" casts only black shadows on her life and on her friends' lives. Lamis seems to be ready to shake "away the silliness [she] had succumbed to" (66). Seen from this perspective, Lamis's memories and recollections help expel dormant feelings of envy and jealousy that could have marred her relationships with her fellow countrywoman like Siham, Huda and Layla.

Layla's memories are sparked repetitively by her daughter's full immersion into American culture and lifestyle, which fuels up Layla's concern and uneasiness. These memories can be clearly seen in two situations in the novel. The first happens on the Parents' Day at Hanan's School where she succumbs to her daughter's wish to not attend because Hanan is embarrassed by her mother's heavily-accented English. Unlike her, both her husband and her daughter are "born in the States, raised here, went to school here" and speak perfect English (100). Following this incident, she remembers her marriage to Michel. The latter married her because "he wanted to keep in touch with his culture" (100). Layla reminds herself how she and Michel agreed that it is the right thing to let their children know their culture and how it matters (102). In other words, this memory re-instills her cultural confidence and the rightfulness of its transmission. As such, their "firstborn child was given an Arabic name," Hanan, that resonates the warmth of Jerusalem (ibid). Being treated indifferently by her daughter, she remembers how "Hanan has been [her] life, despite her reluctance" (ibid). Hanan's independence prompts Layla to think of her own childhood. Experiencing a traumatizing childhood, Layla grows up with the fear of being left behind. Layla also remembers the horrors of the 1967 war where her own mother, brother, and herself were fleeing from 
Ramallah due to the war. She remembers how at those times she "didn't want to be left behind" (104). Afraid that she would be left alone by her daughter, she decides to write a letter to Hanan to explain what she fails to do in a face-to-face encounter with her daughter. Accordingly, by drawing on her memories, Layla is moved to take an action by opening her heart to her only child. She sets a bridge to communicate with her daughter in spite the cultural differences and the wide generational gap.

The final memory narrative is that of Huda, Reema's mother. Huda's narrative entails what Hirsh (2002) calls "postmemory." This is evident in the novel at large and in the closing narrative which is narrated by Huda. Furthermore, postmemory "would be retrospective witnessing by adoption. It is a question of adopting the traumatic experiences-as thus also the memories - of others as experiences one might oneself have had, and thus of inscribing them into one's own life story" (76, emphasis in original). Indeed, Huda's narrative is an interview that serves as a re-witnessing of the traumatizing war and fleeing from Haifa. This part which is titled "The Scent of Oranges" is not sandwiched in her daughter's narrative parts but distinctively comes at the end as it involves a memory transmission rather than memory-telling. In the interview, Huda tells Reema about the war and postwar trauma that she experiences as a child and adult. The mother narrates how the fire drill alarm in her new school in Philadelphia sends her back in time to the classroom in the UNRWA school in the camp. During these days, the sirens rang often as the Israeli planes soared around, places blown up, and people killed. She goes back to the date where "most of the Palestinians in Haifa were thrown out" (193). Forced to move out, Reema's mother, like other Palestinians, left their home with pockets filled with oranges. The latter becomes a scent of memory that became rubbed on her skin forever. Even when she was hiding in the school's closet, and "even though [she] knew that the pine cleaner odor surrounded [her, she] still smelled fresh oranges" (194).

The reason behind transmitting these memories is to universalize the first-generation experiences and keep Huda's memory alive. Huda, as Yousef Awad puts it, "reminds her daughter of her responsibility, as a writer, to keep alive these stories" (6). Indeed, for women, the act of writing is an act of storing and inscribing. Furthermore, Liedeke Plate (2011) considers women's rewriting as "an act of memory [. . . ] an act of re-collection" itself (3). Read in tandem with Hirsh's insightful comments on "postmemory," one may convincingly argue that it is by taking her mother's stories that Reema, a second-generation Arab American, inscribes her mother's memories into her own life. In other words, the interview permits Reema to re-live her mother's traumatic memories of war and immigration. Subsequently, Reema's research project is not different from Darraj's novel as it "presents the memories of a generation of displaced Palestinian women, and hence, can be viewed as 'a reclaiming of history"' (Awad, 6). This act is not just a reclaiming of history but also an immortalization of the experiences of first generation Arab women immigrants. Indeed, the mothers' memory narratives play a crucial role in the lives of their daughters.

To start with Reema's project, one may suggest that it is the threshold where not only past and present realms meet, but also the worlds of first and second generation Arab American women. It is "an attempt to overcome feelings of meaningless and discontinuity and provide personal and national history with linkage that it seems to be missing" (Haugbolle, 194). Reema's PhD project is a collection of stories related by both immigrant women and their American-born children. It concentrates on the distinctive experiences of both generations and their endurance within the borders of exile. Her motivation and interest arise from her own family's positionality as immigrants. Like Darraj herself, Reema "was becoming a collector of stories" (Darraj, 180). In the words of Alice Walker, through listening to her mother's stories, Reema has "absorbed not only the stories themselves, but something of the manner in which [her mother] spoke, something of the urgency that involves the knowledge that her stories-like her life-must be recorded" (407). As such, memory narratives of the women survivors of war and immigrants' children narratives of endurance empower Reema into strengthening a sense of identity that grows as a feminist writer.

In a narrative titled "intervention," the memory presented is a memory of difference and foreignness which is exactly the thing that still haunts Reema's relationship with her narrow-minded boyfriend Alex. It is the memory of a second-generation experience. Reema is reminded of her childhood time where she first came to experience ethnicity bullying. She "had never felt like an outsider until she was in the fifth grade, when her aunt, who was visiting from the West Bank, showed up with her mother to pick her up after school" (181). This aunt was wearing a hijab. After this visit, Reema's life has changed dramatically. She is now bullied in school being called a "towelhead" (181). By the end of that year, each of Nadia, Hanan, and Aliyah, "had joined their camel jockey circle" (181). Such stereotypes represent the harsh processes of assimilation that second-generation immigrants suffer. Consequently, this memory narrative shows Reema's awareness of her situatedness as a second generation immigrant along with other women immigrants and her belongingness to her mother's "her-story."

Like Reema, Aliyah's empowerment as a writer comes due to recollecting past narratives that she has meticulously collected and classified in her journal. She narrates past reminiscences of her journey to Jerusalem. It voices her feelings of in-betweenness and marks a crisis of her cultural identity. Aliyah remembers how her feelings of foreignness are deepened by her journey back home. She was rejected due to her Americanness. In other words, Aliyah "bemoans that her position as half American half Arab alienates her from both cultures" (Awad, 5). Thereof, such memory deepens Aliyah's feelings of alienation from both cultures. Her memory book becomes the bank of her literary writings and her life storyline. This act of writing personal stories is therapeutic in the way it allows confessional dimension. As Leigh Gilmore puts it, narratives of one's own life "invoke [...] therapeutic aspects of confession" (xv). Undoubtedly, writing the self becomes a revealing mode of the burdens of the past. As such, memory narration is a therapeutic narrative. 
Nadia's memories are recollections of loss that arise from the loss of her father. He symbolizes the meaning of home for her. Losing him means losing home. Nadia wishes she had "known [her] father better than [she] had. [She] ha[s] only scattered memories" (38). During a visit to the hospital where her father died, she is reminded of the traumatizing memory of her father's death, fifteen years ago. She remembers how frustrated "inconsolable, [and] scared" upon the death of her father (40). Like her father, she has a car accident by which she loses any chance of having children. Her memory of her father and her mother's endurance empowers Nadia into leading a successful life. She refuses to live on the memory of her father's loss. Remembering how strong her mother was, Nadia chooses to move on and be just "a survivor, like [her] mother" who lives up after the loss of her husband (46). Nadia leads a successful career as an intern with the Brookes Company even after the tragic accident.

The final memory narrative, and by far the most elaborate, by a second-generation Arab American woman is related by Hanan. Hanan's narrative is about cultural discomfort and childhood insecurity. Layla, Hanan's mother, "wanted her [daughter] to feel as helpless as she did" (112). Seeing her parents' fear, Hanan decides that she will help herself from now on and does not need the pity and help of anyone (114). Her feelings of insecurity come also from the ignorance of her cultural background. She feels herself "a lost cause. [Her] mother has never shown [her] a map, and [she's] heard these stories a million times" (109). Hanan feels that her mother's homeland is a story that is detached and disconnected from concrete reality. The stories about this "back home" seem like fairytales to her (ibid). Unsecured, Hanan's independency spirit is boosted.

These feelings are even deepened by feelings of cultural discomfort, as well. Her mother constantly scolds her cultural transgressions and her rejection of her Arab identity. These embarrassing memories "would pop into her mind at the most unexpected moments. It was at such moments ... that the memory of her mother's lopsided frown and flared nostrils would hit her like a punch in the stomach" (80). It is the memory when Hanan was sitting next to her elderly uncle Ibrahim. Hanan unmindfully crosses her legs showing her uncle "the bottom of [her] foot" (80). Her mother is gravely infuriated by such insult. Beaten in "a cultural war," Hanan retreats to her room where "she finally [feels] safe in her fortified room, she decide[s] she was not an Arab" (81). Hanan builds a cultural wall between herself and her mother. She distances her present from her mother's past. Consequently, she rejects her ethnic identity by dismissing her mother's memories.

Fighting this cultural tag and ethnic belonging, Hanan finally succumbs to some cultural tolerance due to a mechanism of postmemory. Her father recounts to Hanan the story of his grandfather's kidnapping by the Ottomans. As a young man, his grandfather was taken by the Ottoman army to participate in the war in Damascus. Yet, when the war is over, he was left there. Surprisingly, his grandfather "walked home ... from Syria to [their] village in Palestine," his journey took "almost two full years ... It was like he'd returned from the dead" (163). In narrating this story, Hanan's father transmits the importance of home and belonging as "Home is everything" (ibid). In Hanan's case, home is not just the geographical belonging but also the familial anchor. Consequently, by the end of the narrative, Hanan reconciles with her mother and tolerates her difference. Moreover, she even engages in a process of "envision[ing] the camps where Mama grew up. After all, [she'd] spent all [her] life hearing about them, so it was natural to picture them for [herself]" (136). Being a second generation Arab American, Hanan re-lives her mother's memory and inscribes it into her own lifeline.

To conclude, Darraj's The Inheritance of Exile centralizes the role of memory in rooting and re-rooting exiles. It is a tale of both first and second generation endurance of hardships and cultural difference. The novel presents the different experiences of immigrants and the dialectical mechanisms of memory in their narratives. Memory stands as the healing force that boosts the characters' sense of selfhood and generational continuity. The mothers' recollections prove to be therapeutic in the way it invites fruitful action. For Siham, memory helps her in her process of settlement and re-adjustment in the borderland. While Lamis's remembrance nurses her behaviorism, Layla's past recollections help her confess her hurt caused by her daughter's indifference. Huda's past narrative serves as a narrative of postmemory that connects different women experiences of trauma and immigration. Through these recollections, they succeed to be active agents of their lives. Memory also empowers the daughters' within the walls of Philadelphia as it instigates creativity, suvivorism, and cultural tolerance. Each of Reema's and Aliyah's past narratives help them become better writers. Nadia's past remembrances boost her survival spirit after her accident. Finally, Hanan's memory narrative helps her move beyond her comfort zone to embraces a cultural difference that her mother represents.

\section{Conclusion}

In Tan's The Joy Luck Club (1989) and Darraj's The Inheritance of Exile (2007), mothers' stories are narratives of pain, loss, silence, and/or subjugation. Yet, through narrating and remembering one's own past, their stories become stories of survival, victory and endurance. The mothers' past "is the key to healing mental injuries of the present ... [it] becomes the source of redemption and mutual perception for members of a migrant family" (Lotfi, 1915). In other words, the mothers' stories are stories of triumph and endurance through the darkest of hours. Indeed, each of Tan's and Darraj's mothers are "all survivors in the sense that they have lived through dark times and have emerged in the new world" (Xu, 6). Each story centers on women's endurance and self-empowerment. In this sense, memory narrative becomes a re-assuring force of the mothers' survival nature. The stories of the mothers represent what Nietzsche calls "memory of the will" where memory becomes an active agent that is sustained by the will to survive (40). What the mothers transfer to their daughters is not only the will to survive but also an ethnic and hybrid self. Such recollections helped the daughters in re-making and identity that is 
hybrid and plural. They enabled them to bridge the present into the past and into the future. In Tan's and Darraj's narratives, remembering becomes a vehicle of empowerment and agency to both mothers and daughters.

Through postmemory strategy, memory becomes a constructing force that empowers the daughters of women immigrants. Remembrance becomes a necessity for the daughters' psychological recovery. The receiving of their mothers' narratives of the past becomes an act of reconciliation. Therefore, Hirsch's concept of postmemory becomes an important agent in the daughters' re-construction of their subjectivity and the undoing of their shame of ethnic selves. The term "postmemory" is useful in understanding the experiences of second-generation immigrants who are made privy to their ancestors' memory narratives. In this sense, postmemory is the concept that "describes the relationship of the second generation to powerful, often traumatic, experiences that preceded their births but that were nevertheless transmitted to them so deeply as to seem to constitute memories in their own right" (Hirsch, 2008, 103). These past experiences of the parents are re-enforced into children's consciousness through means of storytelling, "images, and behaviours among which they grew up" (106). In The Joy Luck Club and The Inheritance of Exile, the daughters' memory is "a second-hand, delayed, and indirect form of memory" (Bos, 98). In fact, these daughters are not just the bearers of their mothers' cultural heritage but they also become cultural agents in a foreign community.

In taking postmemory from the prism of feminism, Hirsch (2012) finds that "it is fruitful not only to search for female witnesses of the first and second generation but also to think about a feminist mode of knowing this past" (98). In this context, the presence of the daughter as the recipient of this memory justifies this feminist theorization of postmemory. Daughters become "agents of transmission, and, through them opening the space of remembrance beyond the line of the family, such a practice of postmemory, particularly, can become an ethical and political act of solidarity and, perhaps, agency" (99). Thereof, postmemory becomes an open line that calls for agency and empowerment of the woman character. Through transmission of memories between a mother and her daughter, a feminist solidarity is then possible. Accordingly, memory is the transmission of survival stories, knowledge, and wisdom from mother to daughter. It is the mending of an incomplete self of a woman by a woman through past stories.

\section{References}

Ahmed, S. (2003). Uprootings/regroundings: Questions of Home and Migration. Oxford: Berg.

Ashcroft, B. (2001), Post-Colonial Transformation. London: Routledge.

Assman, J. (2008). Communicative and Cultural Memory. In A. Nünning, and A. Erll, (Eds.), Cultural Memory Studies: An International and Interdisciplinary Handbook. Berlin: Walter de Gruyter.

Awad, Y. (2012). The Arab Atlantic: Resistance, Diaspora, and Trans-cultural Dialogue in the Works of Arab British and Arab American Women Writers. Saarbrucken: Lambert.

Awad, Y. (2015). Displacement, Belonging and Identity in Susan Muaddi Darraj's The Inheritance of Exile. Studies in Literature and Language, 10 (2), 1-10.

Awad, Y and Zuhair, T. (2017). Hideous Hydropolitics in Darraj's A Curious Land. Arab Studies Quarterly, 39 (2), $842-860$.

Barkan, E. R. (2013) Immigrants in American History: Arrival, Adaptation, and Integration. California: ABC-CLIO.

Baronian, M., Besser, S. and Jansen, Y. (2007). Diaspora and Memory: Figures of Displacement in Contemporary Literature, Arts and Politics. Amsterdam: Rodopi.

Bos, P. R. (2007). Adopted Memory: The Holocaust, Postmemory, and Jewish Identity in America. In M. Baronian, S. Besser and Y. Jansen (Eds), Diaspora and Memory: Figures of Displacement in Contemporary Literature, Arts and Politics. Amsterdam: Rodopi.

Bosch-Vilarrubias, M. (2016). Post-9/11 Representations of Arab Men by Arab American Women Writers: Affirmation and Resistance. New York: Peter Lang.

Breuer, J. and Freud, S. (2000), Freud and Breuer: Studies on Hysteria. USA: Basic Books.

Connerton, P. (1989). How Societies Remember. Cambridge: Cambridge UP.

Darraj, S. M. (2007), The Inheritance of Exile: Stories from South Philly. Notre Dame: University of Notre Dame Press.

DeHay, T. (1994). Narrating Memory. In A. Singh, J. T. Skerrett, and R. E. Hogan (Eds.), Memory, Narrative \& Identity: New Essays in Ethnic American Literatures. Boston: Northeastern UP.

Feng, G. and Du, Z. (2015). Traditional Chinese Rites and Rituals. Newcastle upon Tyne: Cambridge Scholars Publishing.

Foster, M. B. (2009). Voice, Mind, Self: Mother-Daughter Relationships in Amy Tan's The Joy Luck Club and The Kitchen God's Wife. In H. Bloom (Ed.), Amy Tan's Joy Luck Club. New York: Infobase Publishing.

Greene, G. (1991). Feminist Fiction and the Uses of Memory. Signs, 16 (2), 290-321.

Guerlac, S. (2006). Thinking in Time: An Introduction to Henri Bergson. Ithaca: Cornell UP.

Haugbolle, S. (2005). Public and Private Memory of the Lebanese Civil War. Comparative Studies of South Asia, Africa and the Middle East, 25 (1), 191-203.

Hirsch, M. (1989). The Mother/daughter Plot: Narrative, Psychoanalysis, Feminism. Bloomington: Indiana UP.

-------. (2002). Marked by Memory: Feminist Reflections on Trauma and Transmission. In N. K. Miller and J. Tougaw (Eds.), Extremities: Trauma, Testimony, and Community. Urbana: University of Illinois Press.

-----. (2012). The Generation of Postmemory: Writing and Visual Culture After the Holocaust. New York: Columbia UP. (2008). The Generation of Postmemory. Poetics Today, 29 (1), 103-128. 
Hirsch, M. and Smith, V. (2002). Feminism and Cultural Memory: An Introduction. Signs, 28 (1), 1-19.

hooks, b. (1991). Narratives of Struggle. In Philomena Mariani (Ed.), Critical Fictions: the Politics of Imaginative Writing. Seattle: Bay Press.

Kayyali, R. A. (2006). The Arab Americans. Connecticut: Greenwood Press.

Liedeke, P. (2011). Transforming Memories in Contemporary Women's Rewriting. London: Palgrave Macmillan.

Ling, H. (1998). Surviving on the Gold Mountain: a History of Chinese American Women and Their Lives. State University of New York Press.

Lipsitz, G. (2001). Time Passages: Collective Memory and American Popular Culture. Minneapolis: University of Minnesota Press.

Lotfi, N. T. (2014). A Unique Approach of Memory Narrative Therapy in Diasporic Contexts: An Analysis of The Bonesetter's Daughter and The Kitchen God's Wife by Amy Tan. Theory and Practice in Language Studies, 4 (9), 1912-1917.

Naff, A. (1985). Becoming American: The Early Arab Immigrant Experience. Carbondale: Southern Illinois UP.

Nietzsche, F. W. (2008). On the Genealogy of Morals: A Polemic: by Way of Clarification and Supplement to My Last Book, Beyond Good and Evil. Oxford: Oxford UP.

Reading, A. (2014). Making Memory Work for Feminist Theory. In M. Evans et al (Eds), The Sage Handbook of Feminist Theory. Los Angeles: Sage.

Rider, J. (1995). The Writer's Book of Memory: An Interdisciplinary Study for Writing Teachers. New Jersey: L. Erlbaum Associates.

Shear, W. (1993). Generational Differences and the Diaspora in The Joy Luck Club. Critique: Studies in Contemporary Fiction, 34 (3), 193-199.

Straub, J. (2008). Psychology, Narrative, and Cultural Memory: Past and Present. In A. Nünning and A. Erll (Eds.), Cultural Memory Studies: An International and Interdisciplinary Handbook. Berlin: Walter de Gruyter.

Tan, A. (2013). The Joy Luck Club, London: Vintage Books.

Wei, W., The Chinese-American Experience: An Introduction, Immigrant and Ethnic America at HarpWeek.com. HarpWeek. http://immigrants.harpweek.com/ChineseAmericans/1Introduction/BillWeiIntro.htm. Accessed 28 Feb. 2018.

White, R. (2008). Freud's Memory: Psychoanalysis, Mourning and the Foreign Body. Palgrave Macmillan.

Wood, M. M. (2012). Negotiating the Geography of mother-daughter relationships in Amy Tan's The Joy Luck Club. The Midwest Quarterly, 54 (1), 82-96.

Xu, B. (1994). Memory and the Ethnic Self: Reading Amy Tan's The Joy Luck Club. MELUS, 19 (1), 3-18.

Zhou, M. (2009). Contemporary Chinese America: Immigration, Ethnicity, and Community Transformation. Philadelphia: Temple UP.

Zong, J. and Batalova, J. (2017). Chinese Immigrants in the United States. Migrationpolicy.org, Retrieved from: www.migrationpolicy.org/article/chinese-immigrants-united-states. Accessed 28 Fev. 2018.

Zuhair, T. and Awad, Y. (2020). Trees, Rootedness, and Diaspora in Susan Abulhawa's Mornings in Jenin. International Journal of Critical Cultural Studies, 18 (2), 11-23. 